\title{
The Effect of Intensive Interval Method Training With Active Recovery and Extensive Intervals and Passive Recovery on 100 Meter Freestyle Swimming Speed
}

\begin{abstract}
R Hutapea
Faculty Of Sport Science, Universitas Negeri Padang, Indonesia

"Corresponding author. Email: rahmathutapea68@gmail.com

ABSTRACT

The purpose of this study was to determine: 1) Effect of Intensive Interval training with Active recovery and Intervals Extensivewith Passive Recovery to the results of the swimming speed of 100 meter freestyle. The type this study is quasi-experimental. The population in this study are all Tirta swimming club athletes and the sample was 16 people. The sampling method used was purposive sampling. The test instruments used in this research wasthe tests of speed of freestyle, while statistical data analysis techniques used were normality test and test-t. The findings shows that: 1) There is influence of interval training with Active Recovery Intensive against swimming speed (pre-test=78.53) and (posttest=74.87) with tcount $=6.28>t$ table $=1.895$ ). 2) There is influence of Extensive interval training with Passive Recovery on swimming speed, (pretest=78.85) and (post-test=74.48) $(\mathrm{t}=5.47>\mathrm{t}$ table $=1.895) .3)$ There is no difference in the effect of interval training with Active Recovery Intensive and Extensive Interval with Passive Recovery on swimming speed is the average post-test interval exercise group Intensive with Active Recovery $(\mathrm{t}=0.385<$ table $=1.895)$. It means the application of this method training will be improve the speed of swimming athlete.
\end{abstract}

\section{Keywords: Training, active recovery, extensive intervals, passive recovery, 100 meter freestyle swimming speed}

\section{INTRODUCTION}

The development of science and technology (science and technology) in the present has brought progress in all fields, one of which is in sports, especially swimming. Swimming is one of the oldest sports and is considered by the world community, especially the Indonesian people who are maritime countries. In an effort to realize and improve Indonesia's human resources, especially in the field of sports, the most important thing that can be done is to pay attention to the development and development of sports for the next generation so that through these sports activities our successors will be a generation that is physically healthy, qualified in their lives and and can be proud of the State of Indonesia in the field of sports. This is as affirmed by Republic of Indonesia Law NO 3 of 2005 concerning National Sports System article 4 which reads: Sport aims to maintain and improve welfare and fitness, achievement, quality of human beings, instill noble moral values, sportsmanship, discipline, strengthen and foster unity and unity nation, strengthen national power, and lift the dignity, dignity and honor of the nation. (Ministry of Youth and Sports) RI.(2007)
From the quotation above, it can be stated that one of the objectives of national sports is to improve and develop human qualities through achievement sports activities, besides that it can also increase physical fitness and instill the values contained in these sports activities, such as sportsmanship and discipline. based on good moral and moral values. As an achievement sport that is competed, it is fitting that development and guidance must be carried out continuously through well-planned and programmed exercises that are supported by science and technology about the sport.In terms of the development of achievement sports for sportsmen it must lead to the objectives to be achieved from these activities such as achieving a achievement that is able to compete in the arena of competition, both at the regional and at the National level (Ihsan. 2018).

In accordance with the opinion of Syafruddin (2005), Ihsan (2014) namely: "sports performance is influenced and determined by the ability of the athlete itself as a whole both concerning his physical abilities, techniques, tactics and by his mental abilities (psychic)". Therefore to fulfill this, athletes must have four components of good achievement.

Freestyle swimming is one of the swimming styles that is contested at every championship, both regional and national levels. In order to have a good quality 
freestyle swimming technique, supporting factors are needed to progress the quality of the swimming technique and if the technique can be done well it is very likely that it will achieve good time and achievements will be easily achieved. Therefore, the quality of a better swimming technique is needed to get the minimum speed or speed as soon as possible.

Based on these quotes, it can be seen that the development and development of sports has become a joint responsibility starting from the central and regional levels. Through the parent organization at the central and regional levels, it is hoped that good guidance will be provided. That is the thing that was also done by the club Garing Tirta Payakumbuh which seeks to foster sports branches initiated by PRSI Payakumbuh, the coaching is carried out through swimming (clubs) found in Payakumbuh. Garing Tirta Payakumbuh swimming club association is a swimming association that continues to actively train its athletes to date with PRSI Payakumbuh, through this training Mr. Gitok Saputra as head coach of Garing Tirta has been able to follow his athletes to take part in O2SN competitions with serious and mature coaching has been carried out by all trainers of the Garing Tirta Payakumbuh swimming association. This can lead these athletes to win every medal in a race in order to achieve maximum performance.

But even so, the achievements of the athlete Garing Tirta Payakumbuh have not yet achieved the achievement desired by the club coach and the desire of PRSI Payakumbuh. For example, in the POPROV event held in Dharmasraya in 2014 only one senior age group athlete won a gold medal to represent the City of Bukittinggi. Based on observations conducted by researchers on February 11, 2015 at the Garing Tirta Payakumbuh pool, club head coach Garing Tirta Payakumbuh said that until now the Garing Tirta club had not yet achieved any achievements nor was the number 200 meters and 400 meters long swimming freestyle and even then for senior age groups.For the 100 meter freestyle sprint number also has not shown maximum achievement until now, especially in the age group 15 to 17 years have not been able to produce maximum achievements in each race that is followed. Based on the club coach's statement, it can be concluded that until now the achievements of the athletes at each race have nothing at all in freestyle swimming numbers such as 200 meters and 400 meters, while for short distance numbers such as the 100 meter style number free, until now the athlete Garing Tirta Payakumbuh has not been able to reach especially in the age group of 15 to 17 years.

The ability of the athlete Garing Tirta Payakumbuh to win a medal in the freestyle swimming number is thought to be influenced by various factors, including: physical condition, mastery of technique, mentality, competence of the trainer, motivation and the exercise program that is implemented. If these factors are not in the proper conditions, to achieve the 100 meter freestyle swimming achievement it is difficult to realize optimally. Because these factors are very closely related to the activities followed by athletes during training sessions. To make an athlete with achievements, of course, seen from the quality of the program being undertaken, the expertise of a coach designs an exercise program and chooses the right training program to improve the athletes' preservation needs to choose, determine, and how to run an exercise program in general. However, the training method used by trainers has been using exercises that only provide directives related to freestyle swimming.

The incompatibility of training methods used with athletes' character while participating in the training also triggers inhibition in achieving effective and efficient training results, based on the character of the club athlete Garing Tirta. recovery, these two methods were chosen as a form of application of increased skills in swimming training at the Garing Tirta Payakumbuh club.

However, you must be able to use a variety of methods that are tailored to the situation and condition of the athlete, which is in accordance with the training period and the level of progress of achievement. From several existing training methods can be used and compared with the aim to improve the ability of children to be trained, so here researchers are interested in comparing two training methods, namely intensive interval training methods with active recovery and extensive intervals with passive recovery. Here the researcher also wants to compare the two training methods with freestyle swimming movements because this style is the force given to swimmers who are already proficient in swimming and one of the numbers competed in swimming.

\section{METHOD}

The research design used was quasi-experimental research (Quasi Experiment). This research is intended to find the difference between intensive interval training and active recovery and extensive intervals with passive recovery on 100 meter swimming speed of the free style of the athlete Garing Tirta Payakumbuh. This study used a two group pretest-posttes design experimental design. According to Suryabrata (2010) "In this design two subject groups were used, namely intensive interval training group with active recovery and extensive intervals with passive recovery.

The population in this study were all athletes of Garing Tirta Payakumbuh which numbered 24 people. The sample in this study was determined only by Garing Tirta swimming athletes Payakumbuh age group (15-17 years) specifically for men, amounting to 16 people. Here the researchers chose the age group 15-17 because this age group had not reached the maximum 
performance that was expected to be expected in the 100 meter swimming pool to date and in terms of numbers more adequate for conducting research than the other age groups and especially male athletes more than with female athletes in the age group 15-17 years.

The instrument in this study was through the freestyle swimming speed test (PRSI, 2002: 7) which results in the speed being measured by a stopwatch. Before the test is carried out the direction and instructions are explained in advance and what provisions will be carried out.

Data collected from the results of the pre-test, posttest was analyzed using normality test and t-test statistics with the calculation steps as follows: 1) Data normality test and homogeneity test, data normality test using Lilliefors and homogeneity test using F test; 2) While the hypothesis test uses a different mean test or $\mathrm{t}$ test with the sample dependent $\mathrm{t}$ test formula

\section{RESULTS AND DISCUSSION}

Effect of Intensive Interval Method Exercises with Active Recovery on Swimming Pool Meters 100 Meters Freestyle GaringTirtaPayakumbuh

From the results of the pre-test group active recovery exercise with the intensive interval, the smallest time was 70.06 seconds, the largest time was 88.01, the average was 78.553 and the standard deviation was 6.837 . From the results of the post-test after being given treatment for 16 meetings, the lowest value of 85.17 was obtained, the highest value of 67.15 was 74.87 and the standard deviation was 6.875 . The results of the intensive interval training group pre-test data analysis with active recovery in the category of nonexistent, good category as many as 3 people $(37.5 \%)$, enough categories as many as 2 people $(25 \%)$, less categories as many as 3 people $(37,5 \%)$, and none at all, and then for the results of intensive interval training group post-test results with active recovery with very good categories of 3 people $(37.5 \%)$, good category as many as 1 person (12.5\%). ), enough categories as many as 4 people $(50 \%)$, there are no less categories, and there are very few categories of athletes who get them.

Effectof Interval Extensive Exercise Methods with Passive Recovery Against Swimming Speed of 100 Meter Freestyle GaringTirta Athlete Payakumbuh

From the results of the pre-test interval training group extensive with passive recovery, the smallest time was 70.07 seconds, the largest time was 87.06 , the average was 78.845 and the standard deviation was 6.457 . From the results of the post-test after being given treatment for 16 meetings the results obtained obtained the lowest value of 80.27 , the highest value of 68.11 the average is 74.478 and the standards are 4.969. The results of the extensive pre-test exercise group analysis of the passive recovery group with nonexistent categories, good categories as many as 2 people (25\%), adequate categories as many as 4 people $(50 \%)$, less categories as many as 2 people $(25 \%)$, and there are not as many categories as there are none, then for the results of group training post-test interval training extensive with passive recovery with very good categories of 2 people (25\%), good categories as many as 2 people $(25 \%)$, sufficient categories as many as 4 people $(50 \%)$, there are no less categories, and there are very few categories of athletes who get it.

There is Significant Effect of Intensive Interval Method Exercise with Significant Active Recovery on Swimming Speeds of 100 Meters Free Style of Tirta Payakumbuh Athlete

Based on the results of the testing of the first hypothesis it was explained that there was a significant effect of intensive interval training with active recovery on the 100 meter swimming speed of the athlete Garing Tirta Payakumbuh, from an average pre-test of 78.53 to 74.87 in the post-test. This is reinforced after the t test is done, where the results of tcount are 6.288 which is greater than $\mathrm{t}$ table at the level of $\alpha=0.05$ of 1.895.These findings are reinforced by previous findings that are relevant where the relevance of this study with the authors' research is to use independent variables, namely intensive interval training methods. According to Meiriani Armen (2011) Analysis of data shows that intensive interval training methods can increase 50 meter freestyle swimming speed, which is an average of 45.50 in the initial test to 44.64 in the final test, where thitung (4.41)> ttable (1.81).

The hypothesis proposed in this study can be accepted, in another sentence it can be said that the practice of intensive interval methods with active recovery has a significant influence on the 100 meter freestyle swimming speed of the athlete Garing Tirta Payakumbuh and accepted the truth emperically.

The increase in the 100 meter swimming ability of this freestyle is likely due to the adaptation of physical training and systematic system programs applied to athletes. As stated in a previous theoretical study, intensive interval training methods with active recovery are a form of speed training method with mild recovery active during the recovery process.

Based on the research that has been carried out we can conclude that the intensive interval training method with active recovery has an effect on the 100 meter swimming speed of the free style of the athlete Garing Tirta Payakumbuh. Therefore, this can be an input for the trainers or athletes themselves to be able to choose and implement this form of training by making it an exercise program. 
There is a Significant Effect of Significant Interval Extensive Method Exercises with Passive Recovery Against Swimming Speeds of 100 Meters Free Style of Garing Tirta Athletes Payakumbuh

Based on the results of testing the second hypothesis it can be concluded that there is a significant effect of the interval training method extensive with passive recovery on the 100 meter swimming speed of the free style of the athlete Garing Tirta Payakumbuh. This is known from the results of the pre-test and post-test, namely from the mean score of 78.85 in the pre-test to 74.48 in the post-test. This is reinforced after the test is done, where the results of tcount are 5.476 which is greater than $t$ table at the level of $\alpha=0.05$ of 1.895 .

These findings are reinforced by the previous findings that are relevant where the relevance of this study with the authors' research is to use the independent variable, namely the extensive interval training method. Meiriani Armen (2011) Analysis of data shows that the extensive interval training method can increase the 50 meter freestyle swimming speed which is an average of 45.81 in the initial test to 44.45 in the final test, where thitung $(5.64)>$ ttable $(1,81)$.

The hypothesis proposed in this study is acceptable, meaning that the hypothesis proposed in this study can be accepted empirically. The interval training method extensive with passive recovery has a significant influence on the 100 meter swimming speed of the free style of the athlete Garing Tirta Payakumbuh.

By applying this extensive interval training method with passive recovery, the athlete Garing Tirta Payakumbuh can increase swimming speed within 100 meters using freestyle swimming. Based on the research that has been carried out, we can conclude that the extensive interval training method with passive recovery has an effect on the 100 meter freestyle swimming speed. Therefore this can be a reference for trainers or athletes themselves to be able to choose and implement this form of training by making it an exercise program.

There are Differences in the Effect Between the Intensive Interval Method Exercise with Active Recovery and Interval Extensive with Significant Passive Recovery Against Swimming Speeds of 100 Meters Free Style of the Tirta Payakumbuh Athlete

After analyzing the results of the study, it can be concluded that from the two forms of exercises, namely intensive interval training with active recovery and extensive with passive recovery intervals described in the previous section, it is clear that each exercise has an influence on 100 meter freestyle swimming speed athlete Garing Tirta Payakumbuh.

But each form of training has different effects, this is because intensive interval training with active recovery and extensive intervals with passive recovery are different from how to do it, but the goal is the same namely increasing speed so that the magnitude of the effect of each exercise is also different against the 100 meter freestyle swimming speed.

To see whether there is a difference in effectiveness between intensive interval training methods and active recovery and extensive intervals with passive recovery on the 100 meter swimming speed of the Garing Tirta Payakumbuh athlete, it can be seen from the tcount $0.385<\mathrm{t}$ table $=1.895$, this means that the null hypothesis is accepted and the research hypothesis is not rejected. Thus it can be interpreted that there is no significant difference between intensive interval training methods with active recovery and extensive intervals with passive recovery on the 100 meter swimming speed of the free style of the athlete Garing Tirta Payakumbuh.

The absence of the influence of the two methods of training is likely due to several factors including: lack of effectiveness in carrying out an exercise program, the ideal duration for carrying out exercises in swimming between 2-3 hours, while researchers running a training program with a duration of 45 minutes and only 3 times a week, because in short the duration of training time is possible for athletes not to be maximal for achieving the goal of training.

Allegedly also caused by infrastructure facilities where the Batang Tabik swimming pool is only 20 meters wide and 35 meters long while the national standard pool size is 50 meters long and 25 meters wide. The Batang Tabik pool also does not have star beams which is an important point to start swimming activities, especially freestyle swimming, because the lack of these infrastructure facilities is likely to be ineffective for doing exercises.

Furthermore, physical factors in this case make it possible for researchers to be less able to motivate athletes in carrying out training, so that athletes do not wholeheartedly run the exercise. There are still many things that can affect the results of training in swimming, but the success or not a method of training is also determined by many things.

According to Syafruddin (2012: 54) "that conducting an exercise program must be considered a variety of factors that will be adjusted by athletes including the burden of having to be adjusted from physical and psychological conditions, facilities and tools, climate and weather conditions, attitudes and social factors". It can be concluded that there is no difference in the effect of intensive interval training with active recovery and extensive intervals with passive recovery due to the burden of training not adjusted to individual athletes' conditions, environment and social conditions. 


\section{CONCLUSIONS}

Based on the analysis and discussion that has been done in the previous chapter, then in this chapter we will give the following conclusions and suggestions: There is the influence of intensive interval training methods with significant active recovery on the 100 meter swimming speed of the free style of the athlete Garing Tirta Payakumbuh significantly, can be proved by data $\mathrm{t}$ count $=6.288>\mathrm{t}$ table $=1.895$. with an average of 78.53 (pre-test) 74.87 (Post-Test) increased by 3.66. There is the influence of the extensive interval training method with significant passive recovery on the 100 meter swimming speed of the free style of the athlete Garing Tirta Payakumbuh, which can be proved by data $t$ count $=5.476>t$ table $=1.895$ with an average of 78.85 (pre-test) 74.48 (Post-Test) increased by 4.37 .

There is no difference in influence between the forms of intensive interval training with active recovery and extensive intervals with significant passive recovery on the 100 meter swimming speed of the free style of the athlete Garing Tirta Payakumbuh. After doing the research and based on the results of the t test, it is proved by tcount $=0.385<\mathrm{t}$ table $=1.895$. The average Post-Test is 74.87 (active recovery with intensive intervals) 74.48 (Passive Recovery with extensive intervals).

Besdies, it is suggested that: 1) For coaches, sports teachers and athletes it is recommended to use intensive interval training with active recovery and extensive intervals with passive recovery in increasing the speed of a swimming athlete, because based on the results of this study results from intensive intervals with active recovery and extensive intervals with passive recovery provide significant influence on sprin speed of a swimmer; 2) For better so that maximum results are obtained, this exercise program should pay attention to everything that supports the achievement of the goals and sincerity of the athlete in the implementation; 3) In the implementation of the exercise, it should be seen the seriousness of the athlete in the implementation of the exercise, because training that does not seriously affect the results of the exercise itself; 4) As a trainer, you must pay attention to the ability of the athlete in preparing the training program to be provided.

\section{REFERENCES}

[1] Adnan, Aryadie, (2005). Tes dan Pengukuran Olahraga. Padang. Fakultas Ilmu Keolahragaan.

[2] Armen, Meiriani. (2011). Pengaruh Metode latihan Interval Intensife dan Interval Ekstensif Terhadap Kecepatan Renang Gaya Bebas 100 Meter. Padang: Tesis, Universitas Negeri Padang.

[3] Arsil,(1999).Pembinaan kondisi fisik.Padang: DIP proyek UNiversitasNegeri Padang.
[4] Counsilman, James. (1986). Competitive swimming manual. Bloomington Indiana: counsilman company.

[5] Dinata, Marta. (2004) Belajar renang. Jakarta : cerdas jaya.

[6] Effendie, S. Anwar. (1985). Dasardasarilmiahkepelatihan. Terjemahan. Semarang: IKIP Semarang Press.

[7] Fardi, Adnan. (2012). Silabusdan hand-out. Mata KuliahStatistik. Padang: Program Pascasarjana

[8] Haller, David. Tanpa tahun. Belajar Renang. Terjemahan oleh Tim Editor Pionir Jaya. 1982. Bandung: Pionir Jaya.

[9] Harsono, (1988). Coaching danaspekaspekpsikologisdalam coaching, Padang: UniversitasNegri Padang.

[10] Hendromatono, Soejoko,(1992). Olahraga pilihan renang. Padang : DIP proyek Universitas Negeri Padang.

[11] Irawadi, Hendri. (2011). Kondisi Fisik dan Pengukuran. Padang: Universitas Negeri Padang.

[12] Maglischo, Ernest. Swimming even faster. PenerbitMcGraw-hill Humanities, social sciences \& orld languages

[13] Marzuki, Chalid. (1999). Renang dasar. Padang: Universitas Negeri Padang.

[14] N Ihsan, zulkifli,Yohandri2018.Instrumen Kecepatan Tendangan Pencak Silat Berbasis Teknologi Jurnal Sosioteknologi 17 (1), 124-131

[15] N Ihsan. 2014. The analysis of the physical condition, will pencaksilat construction training center students (PPLP) of West Sumatra. International Seminar of Sport Culture and Achievemalet, 307,

[16] Orr, rob dan Jane. (2008). Dasar-Dasar Renang. Penerbit Angkasa Bandung.

[17] Syafruddin, (2005). Ilmu kepelatihan olahraga. Padang: Universitas Negeri Padang.

[18] Thomas,David G. Tanpa Tahun. Renang. Tingkat Pemula. Terjemah Oleh Alfons Palangkaraya. 2006. Jakarta: PT. Rajagrafindo Persada

[19] Undang-Undang Sistem Keolahragaan Nasional No 3. 2005. Jakarta: PT Sinar Grafika. 